\title{
MORPHOLOGICAL RESEARCH ON FREE-RESIDUE OXIDATION PROCESSES IN CASES OF DECIDUAL CELLS OF PLACENTA IN CHORIOAMNIONOTIS AND BASAL DECIDUITIS COMBINED WITH IRON-DEFICIENCY ANEMIA IN THE PREGNANT
}

\author{
V. V. Ilika \\ BUKOVINIAN STATE MEDICAL UNIVERSITY, CHERNIVTSI, UKRAINE
}

Background. The oxidative modification of proteins is lately pivotal to pathologists and it is a new way of research on different pathological conditions, as well as the diagnostics of inflammation processes in placenta.

Objective. The study was aimed at the research of nitro peroxides and establishing the specific features of oxidative modification of proteins in inflammation of placenta with iron deficient anaemia in the pregnant.

Methods. Chemiluminescent and histochemical technique (with bromphenol blue on 'acidic' and 'basic' proteins according to Mikel Calvo) was applied.

Results. The intensity of nitro peroxides glow in chorioamnionitis and basal deciduitis increased in comparison with the samples of physiological and iron deficient anaemia gestation. At the same time in chorioamnionitis the glow intensity is higher than in basal deciduitis.

Due to the results of immune histochemical technique held while analysing the samples, together with chorioamnionitis and basal deciduitis the R/B increases and in basal deciduitis the rate, is probably, higher, than in chorioamnionitis. At the same time, the extent of oxidative modification of proteins in cases of inflammation with iron deficient anaemia in the pregnant is on the average higher than with no iron deficient anaemia in the pregnant.

Conclusions. High level of nitro peroxides in placentae basal plate in secundines inflammation, the increase in $R / B$ rate, in other words the prevalence of 'acidic' proteins over 'basic' ones, is evidenced due to the increase of the intensity of oxidative modification processes of proteins in cases of deciduitis.

KEY WORDS: inflammation; placenta; anaemia; iron-deficiency.

\section{Introduction}

The formation of active forms of oxygen and oxidative modification of macromolecules is usual and important biological processes. But the creation of oxygenous residues excess could damage cells and facilitate the development of many illnesses [1], and in certain cases, a molecular pathology of the organism [2].

The oxidative modification of proteins is lately pivotal to pathologists [3], and it is a new way of research on different pathological conditions [4], as well as the diagnostics of inflammation processes in placenta [5]. In this area the scholars used a range of techniques aimed at detection of nitro peroxides [6], as the most

Corresponding author: Vitaliy Ilika, Department of Pathologic Anatomy, Bukovinian State Medical University, 15 Chelyuskintsev Street, Chernivtsi, 58000.

Phone number: +380951477073

E-mail: ilika.vitaliy@mail.ru responsive and long lasting oxidants among free residues, and at estimation of the degree of protein oxidative modification in various structures of placenta [7]. However, this aspect in combination with iron deficient anaemia in the pregnant has not been explored yet [8] and has been being studied that is the objective of our study.

\section{Objective}

Chemiluminescent technique with luminol was applied in the research of nitro peroxides in cases of inflammation. The aim of the study was to establish the specific features of oxidative modification of proteins in cases of deceduitis of basal plate in long lasting basal deciduitis and chorioamnionitis in combination with iron deficient anaemia and without it in the pregnant by means of immune histochemical and micro spectral photometric procedure. 


\section{Methods}

The control group consisted of placenta $(n=20)$ received at the urgent delivery of clinically healthy women in childbirth and in cases of iron-deficiency anaemia in gravidas $(n=21)$. Experimental group consisted of the placenta $(n=123)$ received from women in childbirth at gestation period of 37-40 weeks with chorioamnionitis and basal deciduitis combined with iron deficiency anemia in gravidas and without it.

The first procedure (a chemiluminescent technique) was performed on the frozen sections of placenta. The luminol originated chemiluminescence was studied under the luminescent microscope LUMAM P8. On digital photomicrographies, obtained by means of computer estimation of glow intensity in a 256 gradations scale: from 0 (glow absence indicator) to 255 (glow top intensity), the quantitative measuring of luminescence was carried out [8].

For validity estimation of averages contrast Student's t-test was used, after positive verification of the samples for normal distribution in it was determined by the Shapiro-Wilk test (computer program PAST 3. 14, free license, O. Hammer, 2016) [9]. For approval or rejection of statistic hypothesis the significant difference $\mathrm{p} \leq 0.05$ was used.

To evaluate the extent of oxidative modification of proteins, Histochemical technique was carried out with bromphenol blue on 'acidic' and 'basic' proteins according to Mikel Calvo [10].

Optic images were converted into digital using the digital camera and were analysed with licensed copy of the ImageJ computer program (1.48, W. Rasband, National Institute of Health, USA) using probe computer spectrometry in the system of colour analysis RGB. According to the designated system of colour analysis the intensity of red and blue colours in coloration was assessed. According to the Mikel Calvo technique, red coloration matches carbonyl groups, whereas blue coloration matches protein amines; therefore establishment of mathematical relation between coloration intensity in two colours (spectrum areas) the $\mathrm{R} / \mathrm{B}$ was received and the extent of oxidative modification of proteins was evaluated (relation of carboxylic and amines) [11,12].

\section{Results}

Chemiluminescent glow of nitro peroxides was evaluated and the level of physiological gestation of placentae was estimated in cases of iron deficient anaemia in the pregnant. The averages are introduced in Table 1.

The results of quantitative indicators of chemiluminescent glow of nitro peroxides and the $R / B$ rate in cases of deciduitis of placenta basal plate in acute and long lasting chorioamnionitis, and basal deciduitis in combination with iron deficient anemia in the pregnant are presented in Table 2.

\section{Discussion}

According to the data above, we should emphasise that in physiological gestation of pregnancy in cases of iron deficient anaemia, significant deviations in any conducted technique was not evidenced. The data in Table 2 proves that in chemiluminescent research technique the intensity of nitro peroxides glow in cases of chorioamnionitis and basal deciduitis increases in comparison with the samples of physiological and iron deficient anaemia gestation. The fact that, in cases of placentitis with underlying iron deficient anaemia in the pregnant, the quantitative indicators are higher than with no anaemia. At the same time, in cases of chorioamnionitis, the glow intensity is higher than in basal deciduitis.

\section{Table 1. The quantitative indicators of chemiluminescent nitro peroxide glow and $R / B$ rate (histochemical technique on 'acidic' and 'basic' proteins with bromphenol blue according to Mikel Calvo) in cases of deciduitis of placenta basal plate in physiological gestation and iron deficient anaemia in the pregnant}

\begin{tabular}{|c|c|c|c|c|}
\hline \multirow{3}{*}{$\begin{array}{c}\text { Basal pate } \\
\text { structures } \\
\text { Decidual } \\
\text { cells of ba- } \\
\text { sal plate }\end{array}$} & \multicolumn{4}{|c|}{ Research groups } \\
\hline & \multicolumn{2}{|c|}{$\begin{array}{l}\text { Observation of physiological gestation } \\
\qquad(n=20)\end{array}$} & \multicolumn{2}{|c|}{$\begin{array}{l}\text { Observation of iron deficient anemia } \\
\text { in the pregnant without inflammation } \\
\text { of secundines } \\
(n=21)\end{array}$} \\
\hline & $\begin{array}{l}\text { Chemilumines- } \\
\text { cent glow of } \\
\text { nitro peroxides } \\
\text { with luminol }\end{array}$ & $\begin{array}{l}\text { Histochemical technique } \\
\text { on 'acidic' and 'basic' } \\
\text { proteins with bromphenol } \\
\text { blue on Mikel Calvo }\end{array}$ & $\begin{array}{l}\text { Chemilumines- } \\
\text { cent glow of } \\
\text { nitro peroxides } \\
\text { with luminol }\end{array}$ & $\begin{array}{l}\text { Histochemical technique } \\
\text { on 'acidic' and 'basic' } \\
\text { proteins with bromphenol } \\
\text { blue on Mikel Calvo }\end{array}$ \\
\hline & $34 \pm 3.8$ & $1.04 \pm 0.008$ & $\begin{array}{l}38 \pm 4.2 \\
p>0.05\end{array}$ & $\begin{array}{c}1.06 \pm 0.009 \\
p>0.05\end{array}$ \\
\hline
\end{tabular}


Table 2. Quantitative indicators of chemiluminescent glow of nitro peroxides and the R/B rate (histochemical technique on 'acidic' and 'basic' proteins with bromphenol blue on Mikel Calvo) in cases of deciduitis of placenta basal plate in acute and long lasting chorioamnionitis and basal deciduitis in combination with iron deficient anemia in the pregnant

\begin{tabular}{|c|c|c|c|c|}
\hline \multirow{2}{*}{$\begin{array}{c}\text { Research } \\
\text { groups }\end{array}$} & \multicolumn{3}{|c|}{$\begin{array}{c}\text { Chemiluminescent glow of nitro peroxides } \\
\text { with luminol }\end{array}$} & $\begin{array}{c}\text { Histochemical technique on 'acidic' and } \\
\text { 'basic' proteins with bromphenol blue on } \\
\text { Mikel Calvo R/B rate } \\
(\mathrm{M}=\mathrm{m})\end{array}$ \\
\cline { 2 - 5 } & $\begin{array}{c}\text { Secundines } \\
\text { inflammation }\end{array}$ & $\begin{array}{c}\text { Secundines inflammation } \\
\text { in cases of iron deficient } \\
\text { anaemia in the pregnant }\end{array}$ & $\begin{array}{c}\text { Secundines } \\
\text { inflammation }\end{array}$ & $\begin{array}{c}\text { Secundines inflammation } \\
\text { in cases of iron deficient } \\
\text { anaemia in the pregnant }\end{array}$ \\
\hline $\begin{array}{c}\text { Acute } \\
\text { chorio- }\end{array}$ & $\begin{array}{c}154 \pm 4.9 \\
\text { amnionitis }\end{array}$ & $\begin{array}{c}186 \pm 5.1 \\
(\mathrm{n}=20)\end{array}$ & $\begin{array}{c}1.24 \pm 0.011 \\
(\mathrm{n}=20)\end{array}$ & $\begin{array}{c}1.64 \pm 0.016 \\
(\mathrm{n}=21) \\
\mathrm{p}=0.003\end{array}$ \\
\hline $\begin{array}{c}\text { Acute basal } \\
\text { deciduitis }\end{array}$ & $\begin{array}{c}130 \pm 4.4 \\
(\mathrm{n}=21)\end{array}$ & $\begin{array}{c}164 \pm 4.5 \\
(\mathrm{n}=20) \\
\mathrm{p}=0.002\end{array}$ & $\begin{array}{c}1.89 \pm 0.015 \\
(\mathrm{n}=21)\end{array}$ & $\begin{array}{c}2.14 \pm 0.018 \\
(\mathrm{n}=20) \\
\mathrm{p}<0.001\end{array}$ \\
\hline
\end{tabular}

The photomicrographs of histological images give an idea of how some structures of placental basal plate look like, decidual cells in particular, when the immunohistochemically technique for 'acidic' and 'basic' proteins according to Mikel Calvo is applied (Fig.1).

When assessing visual histochemical preparations, decidua cells are clearly stained that is applicable for quantitative research, cell boundaries are defined by clear cell membrane colouring and contrasting colour around decidua cells fibrinoid. Nuclei and nucleoli were visualized fairly well. 'Basic' proteins prevailed in nucleoplasm, while 'sour' in the nucleolus.

The decidua cells cytoplasm specific colour was mostly granular in nature and spectral characteristics and optical density of colour varied greatly.

Relatively invariable data in assessing the degree of oxidative modification of proteins in



Fig. 1. Photomicrograph of placental basal plate. Histochemical technique for 'acidic' and 'basic' proteins with bromphenol blue according to Mikel Calvo. On the right - observation during physiological pregnancy. On the left - in cases of chronic deciduitis in placental basal plate.

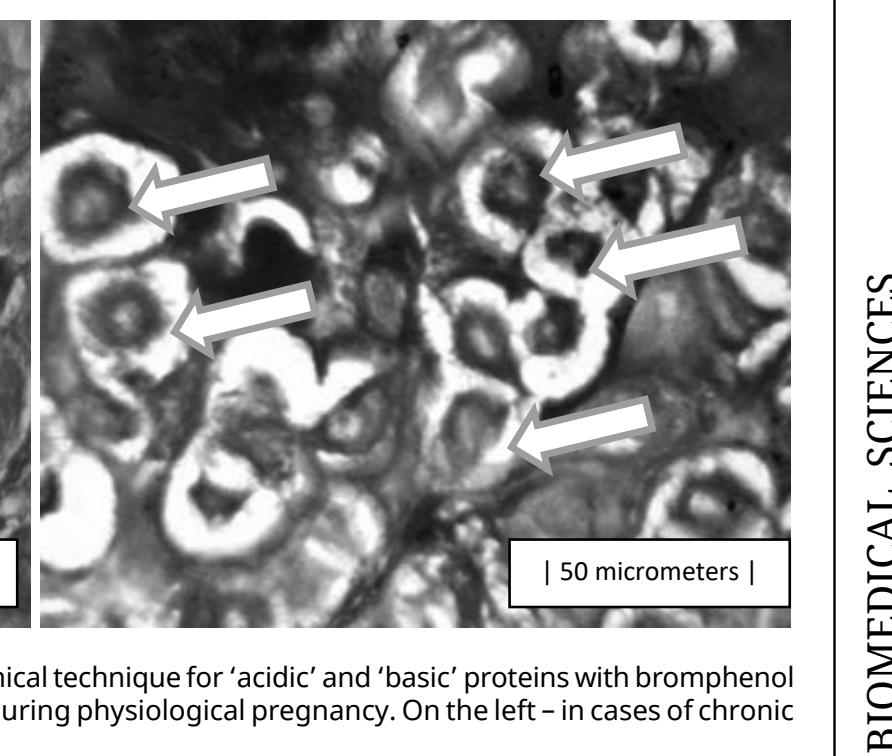

placentas of physiological gravidity and gravidas are observed, which can be interpreted as the manifestation of involutory changes in placenta. The R/B factor is only slightly higher than what can be evaluated as a slight predominance of 'sour' proteins over 'basic' ones. These figures are important in terms of the R/B factor assessing, as an indicator of oxidative modification of proteins. However while analysing the samples with chorioamnionitis and basal deciduitis the R/B increases and in basal deciduitis the rate is probably higher than in chorioamnionitis. At the same time, the extent of oxidational modification of proteins in cases of inflammation in combination with iron deficient anaemia in the pregnant is on the average higher than with no iron deficient anaemia in these patients.

Taking into account our findings of high level of nitro peroxide in basal lamina of placen- 
tas which are characterized by secundines inflammation, increase in, i.e. the prevalence of 'sour' proteins over 'basic' ones; correlation between the increasing intensity of oxidative modification of proteins in cytoplasm of deciduitis and secundines inflammation would be reasonable.

\section{Conclusions}

Due to the chemiluminescent technique of nitro peroxides evaluation and immune histochemical technique of 'acidic' and 'basic' proteins assessment in cases of deciduitis of placenta basal plate, the impetuous increase of indicators is observed.

The inflammation of secundines in combination with iron deficient anaemia in the pregnant was evidenced by higher average rates than with no anaemia.

Considering the received data that proves high level of nitro peroxides in placentae basal plate in secundines inflammation, the increase in $\mathrm{R} / \mathrm{B}$ rate, in other words prevalence of 'acidic' proteins over 'basic' ones, is evidenced due to the increase of intensity of oxidative modification processes of proteins in cases of deciduitis.

\section{References}

1. Reactive oxygen species and oxidative modification of macromolecules: the benefits, harm and protection. http://www.pereplet.ru/obrazovanie/ stsoros/696.html

2. Gubskyi YI. Cell death: free radicals, necrosis, apoptosis: the monograph. Vinnytsia New Book. 2015;67-101.

3. Ben Messaoud Ershyd, Davydenko IS. Protein oxidative modification in the cytoplasm of epithelial cells of the endometrium in its various states of nonneoplastic and neoplastic nature. Clinical anatomy and operative surgery. 2008;1:25-29.

4. Muravleva LE, Molotov-Luchanskyi VB, Kliuiev DA, Bakenova RA, Kultanov BJ, Tankibaeva NA, Koikov VV and oth. Protein oxidative modification: Problems and research perspectives. Fundamental research. 2010;1:74-78.

5. Benirschke K, Burton GJ, Baergen RN. Pathology of the human placenta. New York Springer. 2012;6:974.

6. Davydenko IS, Davydenko OM. Nitro peroxide chemiluminescent determination in the cytoplasm of placental plasmodium chorionic villi in the placenta with purulent chorioamnionitis. Proceedings of VIII International Congress of pathologists of Ukraine "Modern problems of pathological anatomy". Poltava. 2008;26-27.

7. Shenderiuk OP, Davydenko IS. Method of measuring protein oxidative modification in the structure of placenta. Patent of Ukraine for invention №13712 U.-17.04.2006. Bull. №4. 2c. (Appl 14.10.2005, №u200509673, BSMU, Shenderiuk OP, Davydenko IS.
Protein oxidative modification in the cytoplasm of placental plasmodium chorionic villi in the placenta with purulent chorioamnionitis (histochemical data). The world of medicine and biology. 2008;2(3):88-90.

8. Ilika VV, Davydenko IS. Nitro peroxide chemiluminescent research in the nidus of inflammation in chorioamnionitis and basal deciduitis in gravidas with iron deficiency anemia. Prospective directions of modern perinatology. Proceedings of the scientific-practical conference with international participation on the occasion of the 100th anniversary of Professor Boryma TV birthday. Chernivtsi Medical University. 2014;108-111.

9. Hammer O. PAST: Paleontological Statistics, Version 3.14. Reference manual. Oslo Natural History Museum University of Oslo. 2016;243.

10. Davydenko IS. Standardization measures of histochemical methods in terms of protein oxidative modification. Ukrainian medical almanac. 2013;3: 180-181.

11. Vorobiova LI, Peresunko OP, Zelinska NV, Davydenko OI. Computer microspectrophotometry of the system "Epithelium-connective tissue" in cervical cancer diagnosis. http://dspace.bsmu.edu. ua:8080/xmlui/handle/123456789/3890. Accessed 2012.

12. Davydenko IS, Davydenko OM. Histochemical peculiarities in protein oxidative modification in the cells of the renal glomeruli in glomerulonephritis with acute postinfectious glomerulonephritis. Bukovyna Medical Journal. 2012;16(3):106-107.

Received: 2017-01-17 